\title{
BMJ Open Social inequalities and dynamics of the early COVID-19 epidemic: a prospective cohort study in France
}

Nathalie Bajos (iD , ${ }^{1}$ Emilie Counil (D) , ${ }^{2}$ Jeanna-eve Franck (D) , ${ }^{1}$ Florence Jusot, ${ }^{3}$ Ariane Pailhé, ${ }^{2}$ Alexis Spire, ${ }^{1}$ Claude Martin, ${ }^{4}$ Nathalie Lydie, ${ }^{5}$ Remy Slama, ${ }^{6}$ Laurence Meyer, ${ }^{7}$ Josiane Warszawski, ${ }^{7}$ for the EpiCoV study group

To cite: Bajos N, Counil E, Franck J, et al. Social inequalities and dynamics of the early COVID-19 epidemic: a prospective cohort study in France. BMJ Open 2021;11:e052888. doi:10.1136/ bmjopen-2021-052888

- Prepublication history and additional supplemental materia for this paper are available online. To view these files, please visit the journal online (http://dx.doi.org/10.1136/ bmjopen-2021-052888)

$\mathrm{EC}$ and $\mathrm{J}-\mathrm{eF}$ contributed equally.

Received 28 April 2021 Accepted 06 October 2021

Check for updates

(c) Author(s) (or their employer(s)) 2022. Re-use permitted under CC BY-NC. No commercial re-use. See rights and permissions. Published by BMJ.

For numbered affiliations see end of article.

Correspondence to

Dr Nathalie Bajos;

nathalie.bajos@inserm.fr

\section{ABSTRACT}

Objective Although social inequalities in COVID-19 mortality by race, gender and socioeconomic status are well documented, less is known about social disparities in infection rates and their shift over time. We aim to study the evolution of social disparities in infection at the early stage of the epidemic in France with regard to the policies implemented.

Design Random population-based prospective cohort Setting From May to June 2020 in France.

Participants Adults included in the Epidémiologie et Conditions de Vie cohort $(n=77588)$.

Main outcome measures Self-reported anosmia and/ or ageusia in three categories: no symptom, during the first epidemic peak (in March 2020) or thereafter (during lockdown).

Results In all, 2052 participants (1.53\%) reported anosmia/ageusia. The social distribution of exposure factors (density of place of residence, overcrowded housing and working outside the home) was described. Multinomial regressions were used to identify changes in social variables (gender, class and race) associated with symptoms of anosmia/ageusia. Women were more likely to report symptoms during the peak and after. Racialised minorities accumulated more exposure risk factors than the mainstream population and were at higher risk of anosmia/ageusia during the peak and after. By contrast, senior executive professionals were the least exposed to the virus with the lower rate of working outside the home during lockdown. They were more affected than lower social classes at the peak of the epidemic, but this effect disappeared after the peak

Conclusion The shift in the social profile of the epidemic was related to a shift in exposure factors under the implementation of a stringent stay-at-home order. Our study shows the importance to consider in a dynamic way the gender, socioeconomic and race direct and indirect effects of the COVID-19 pandemic, notably to implement policies that do not widen health inequalities.

\section{INTRODUCTION}

The COVID-19 pandemic that has been hitting the world since the beginning of the year 2020 has reinforced and strengthened social inequalities in health. ${ }^{1-3}$ This evidence mostly comes from mortality-based
Strengths and limitations of this study

- Epidémiologie et Conditions de Vie is a large random socioepidemiological prospective cohort including both detailed social characteristics, exposure risk factors and date of first COVID-19-like symptom(s), enabling us to study the dynamic of the pandemic social profile.

- We focused on the most specific symptoms of SARSCoV2 infection-anosmia/ageusia-that makes our analyses more robust.

- Our outcome is based on reported symptoms rather than on biologically confirmed cases due to the lack of tests at the time of the survey.

- Highly vulnerable populations, such as homeless people, are not represented in our sample.

studies. ${ }^{45}$ Few studies are based on the incidence of COVID- $19,{ }^{6}$ while the disease has an infection case-fatality ratio below $1 \%{ }^{7}$ Most of these analyses are from the USA and the UK, which have strong specificities in terms of healthcare systems and social and ethnic inequalities. They are based on ecological studies, not allowing to consider socioeconomic inequalities at the individual level and to adjust for potential confounders. ${ }^{4}$ In addition, the literature very little addressed the dynamics of social inequalities as the epidemic evolves and prevention measures are implemented, measures that may themselves have differential efficiency across social and ethnic groups and between sexes. Notable exceptions are Wright $e t a l^{8}$ (in the UK) and Jefferies et at (in New Zealand), who found trends towards lower risk of suspected COVID-19 and lower testing rates of SARS-CoV-2 among people of lower socioeconomic status during the early weeks of the epidemic and a higher risk and higher testing rates subsequently.

Few studies showed that the prevention policies put in place, in particular the mobility restrictions and the strong incentive to work 
remotely, were more beneficial to the most privileged classes in terms of disease incidence. ${ }^{10}{ }^{11}$ This suggests that the social distribution of exposure factors may have changed over time, as has been previously found for other influenza pandemics. ${ }^{12} 13$

Our objective was to study the dynamics of gender, race and social class-related inequalities in COVID-19 disease incidence at the early stage of the epidemic in France. We adopted an intersectional approach ${ }^{14}$ that simultaneously takes into account these three social factors. ${ }^{15}$

We first compared the occurrence of reported anosmia and/or ageusia-a specific proxy of disease incidence-by sociodemographic characteristics between the first peak of the epidemic, around 19 March 19 , until the beginning of June 2020, when the incidence decreased following the first lockdown. ${ }^{16}$ Then we studied how the distribution of three important risk factors of COVID-19 exposure and infection, that is, population density, overcrowded housing and working outside the home, ${ }^{17}$ varied across sociodemographic groups. Finally, we studied how the association of social characteristics with anosmia/ageusia evolved during and after the epidemic peak while adjusting for exposure risk factors and health variables.

\section{PARTICIPANTS AND METHODS}

\section{Study design and participants}

The Epidémiologie et Conditions de Vie (EpiCoV) cohort was set up in April 2020, with the general aim of understanding the main epidemiological, social and behavioural features of the COVID-19 epidemic in France. The data collection period ran from 2 May to 2 June 2020. In France, strict lockdown expanded from 17 March to 10 May, and the first epidemic peak was recorded around 19 March. $^{16}$

A stratified random sample of 350000 people aged 15 years and over was drawn from the tax database of the National Institute of Statistics and Economic Studies (INSEE), which covers $96 \%$ of the population living in France but excludes people living in institutional settings. People belonging to the lowest decile of income were over-represented. A total of 134391 (38.4\%) participated in the survey. Individuals were invited to answer the questionnaire online, or by phone if they did not have internet access.

We used reweighting and marginal calibrations in the survey and sampling design to correct for nonparticipation bias. We focused on people living in metropolitan France, aged 18-64 years, in order to take into account working arrangements and type of occupation in the analysis $(\mathrm{n}=98787)$.

\section{Patient and public involvement}

Patients and/or the public were not involved in the design, or conduct, or reporting, or dissemination plans of this research.

\section{Outcome}

Participants were invited to report COVID-19-like symptoms (such as cough, fever, dyspnoea, anosmia and/or ageusia), if they were unusual and if they were present at or occurred since the beginning of the lockdown. They also reported when the first symptom appeared. The main health outcome studied here was reporting symptoms of anosmia and/or ageusia, the most specific symptoms of SARS-CoV2 infection. ${ }^{17-19}$ Among those who did not report anosmia/ageusia, the analysis was restricted to people without reported cough, fever or dyspnoea in order to exclude possible COVID-19 cases $(\mathrm{n}=14080)$. Individuals whose symptoms started before lockdown were also not considered in the analysis to avoid overrepresentation of long-lasting forms of COVID-19 $(\mathrm{n}=844)$.

A distinction was made between those people whose first symptoms began more than 1 month before their response to the survey, likely to have occurred during the epidemic peak, and those whose first symptoms began less than 1 month before, likely to have occurred after the peak, during the epidemic decline phase (during and early after lockdown). Our outcome was in three categories: no reported anosmia/ageusia (nor cough, fever or dyspnoea), anosmia/ageusia starting during the epidemic peak and anosmia/ageusia starting after the epidemic peak.

\section{Sociodemographic variables}

We considered the following six variables: age, sex, ethnoracial status (based on migration history), social class (based on current or most recent occupation combined with education), standard of living (based on decile of income per household consumption unit) and formal education (defined according to the hierarchical grid of diplomas in France). The ethnoracial status distinguished mainstream population, that is, persons residing in metropolitan France who are neither immigrants nor native to French Overseas Departments (DOM, ie, Martinique, Guadeloupe and Reunion Island), nor descendants of immigrant(s) or of DOM native. ${ }^{20}$ For the minority population, a distinction was made according to the first (immigrants) and second (descendants of immigrants) generations of immigration and the country of origin. The term racialised refers to people from the Maghreb, Turkey, Asia and Africa.

\section{Exposure risk factors}

We considered three main risk factors of exposure to COVID-19: having worked outside the home during lockdown (at least partly), high density of the place of residence (ie, at least 1500 inhabitants per $\mathrm{km}^{2}$ and a minimum of 50000 inhabitants) and overcrowded housing (ie, at least two persons living in housing with less than $18 \mathrm{~m}^{2}$ per person) both assessed using the official national definitions. Additional explanatory variables included self-reported essential occupations and household size. To account for regional variations in incidence, 
we distinguished between the least affected and the three most affected regions at the time of the survey.

\section{Health variables}

Health variables included smoking habits, self-reported history of chronic diseases and body mass index.

\section{Statistical analyses}

We first studied the association between the three social variables of interest (gender, race and social class) and anosmia/ageusia, distinguishing between the two periods, and then with the exposure risk factors (density, overcrowding and working outside) using $\chi^{2}$ test. To study how the social characteristics associated with anosmia/ ageusia evolved during and after the epidemic peak, we further developed a step-by-step multinomial analysis adjusted for (l) age and social variables (M0), (2) then adding the three main exposure variables and regions (M1) and (3) finally adding health variables (M2).

Observations with missing values on anosmia/ageusia or main social and exposure variables were excluded from our analysis $(\mathrm{n}=6275,7.5 \%)$. In all, 77588 individuals were included in our analyses. All analyses were weighted using a Heckman model to take into account the effect of the response mode on the reporting of COVID-19-like symptoms. ${ }^{21}$ Analyses were performed with the SAS software V.9.4. A $p$ value $<0.05$ was considered statistically significant.

\section{RESULTS}

\section{Gendered differences}

Women were more likely to have been affected by anosmia/ageusia: $1.84 \%$ of women versus $1.22 \%$ of men $(\mathrm{p}<0.01)$ (table 1). Sex was not strongly associated with most risk factors of anosmia/ageusia, with the exception of working outside home $(50.6 \%$ in men vs $44.7 \%$ in women, $\mathrm{p}<0.001$ ) (table 2). The significant association of anosmia/ageusia with gender only weakly attenuated over time, with the crude OR decreasing from $1.57(95 \%$ CI 1.40 to 1.76 ) to 1.40 (95\% CI 1.14 to 1.71 ) (table 3 ). While adjusting for other social characteristics (M0), exposure risk factors (M1) and health variables (M2) did not strongly attenuate the association, inclusion of essential occupations did (online supplemental table 1).

\section{ETHNORACIAL STATUS}

If we now consider ethnoracial affiliation, we find that all minority groups, to varying degrees (from $1.79 \%$ to $2.67 \%$, table 1), reported anosmia more often than the majority population $(1.35 \%, \mathrm{p}<0.001)$.

Ethnoracial affiliation was strongly associated with exposure risk factors, with the exception of working outside home. For example, $72.6 \%$ of the racialised first-generation immigrants reported living in a highdensity place of residence (compared with $31.8 \%$ for the mainstream population, $\mathrm{p}<0.001)$ and $41.4 \%$ in an overcrowded housing (compared with $8.7 \%$ for the mainstream population, $\mathrm{p}<0.001$, table 2 ).
Over-risk of reporting anosmia/ageusia was recorded among racialised minorities both during and after the epidemic peak (crude models), although non-significant after the peak for non-racialised second-generation immigrants and racialised first-generation immigrants (table 3). Adjusting for the exposure risk factors that significantly attenuated the observed associations, both during and after the peak (M1). After further adjusting for health variables, only racialised second-generation immigrants (respectively 1.48 (95\% CI 1.19 to 1.83 ) and 1.42 (95\% CI 1.00 to 2.01) during and after the peak), DOM or descendants of DOM native $(1.50$ (95\% CI 1.07 to 2.12) during the peak) and non-racialised firstgeneration immigrants (1.77 (95\% CI 1.04 to 3.04) after the peak) remained at higher risk of reporting anosmia/ ageusia compared with the mainstream population (M2).

\section{Social class}

There were marked differences between occupational classes. The top categories appeared to be most affected by anosmia/ageusia: $1.89 \%$ for middle executive professionals, $1.81 \%$ for senior executive professionals and $1.83 \%$ for skilled employees, against $0.99 \%$ for skilled and $1.11 \%$ for low-skilled manual workers (table 1 ).

These social groups are differently exposed to risk factors. Although senior executive professionals are more likely to live in high-density areas than low-skilled manual workers (53.5\% compared with $27.4 \%$ ), they are less likely to live in an overcrowded accommodation $(10.3 \%$ compared with $17.5 \%$ ) and have more often been able to telework during the lockdown $(39.2 \%$ have worked outside the home compared with $56.9 \%$ for low-skilled manual workers, table 2).

Marked evolutions are observed over time. In crude models, while the lower social categories and selfemployed were significantly less affected than senior executive professionals during the peak, this most privileged social category did not appear to be more at risk of anosmia/ageusia than the others after the peak (table 3). Only middle executive professionals were at increased risk after the peak, and only simultaneous adjustment on exposure risk factors, health variables, essential occupations and regions lowered this association towards the null (online supplemental table 1).

\section{DISCUSSION}

\section{Main study results}

Our results are based on data documenting exposure factors and symptoms during the first epidemic wave. By distinguishing infections that probably occurred at the time of the epidemic peak (just before or in the very first days after the start of lockdown), from those which occurred later (during and early after the lockdown, as the epidemic declined), a change in the social profile of the affected people emerged. This allowed us to unmask social characteristics and exposure risk factors that increased the risk of infection during and/or after the 
Table 1 Sociodemographic characteristics associated with anosmia/ageusia

\begin{tabular}{|c|c|c|c|c|}
\hline & $\begin{array}{l}\text { Anosmia/ } \\
\text { ageusia, } \\
n=2052(1.53 \%)\end{array}$ & $\mathrm{P}$ value† & $\begin{array}{l}\text { Anosmia/ageusia } \\
\text { during peak, } n=1521 \\
(1.12 \%)\end{array}$ & $\begin{array}{l}\text { Anosmia/ } \\
\text { ageusia after } \\
\text { peak, } n=531 \\
(0.41 \%)\end{array}$ \\
\hline Age (years) & & $<0.001$ & & \\
\hline $18-24$ & $253(1.27)$ & & $168(0.86)$ & $85(0.41)$ \\
\hline $25-34$ & $431(1.92)$ & & $322(1.43)$ & $109(0.48)$ \\
\hline $35-44$ & $510(1.83)$ & & $379(1.33)$ & $131(0.50)$ \\
\hline $45-54$ & $521(1.57)$ & & $407(1.22)$ & $114(0.35)$ \\
\hline $55-64$ & $337(1.07)$ & & $245(0.76)$ & $92(0.31)$ \\
\hline Sex & & $<0.001$ & & \\
\hline Men & $773(1.22)$ & & $570(0.88)$ & $203(0.34)$ \\
\hline Women & $1279(1.84)$ & & $951(1.37)$ & $328(0.47)$ \\
\hline Ethnoracial status & & $<0.001$ & & \\
\hline Mainstream population & $1454(1.35)$ & & $1075(0.98)$ & $379(0.36)$ \\
\hline Non-racialised first-generation immigrants & $94(2.20)$ & & $69(1.48)$ & $25(0.72)$ \\
\hline Non-racialised second-generation immigrants & $108(1.79)$ & & $80(1.37)$ & $28(0.42)$ \\
\hline Racialised first-generation immigrants & $164(1.86)$ & & $127(1.43)$ & $37(0.43)$ \\
\hline Racialised second generation immigrants & $170(2.62)$ & & $125(1.95)$ & $45(0.67)$ \\
\hline DOM or descendants of DOM native & $62(2.67)$ & & $45(1.95)$ & $17(0.72)$ \\
\hline Social class & & $<0.001$ & & \\
\hline Self-employed and entrepreneurs & $92(1.39)$ & & $63(0.91)$ & $29(0.48)$ \\
\hline Senior executive professionals & $454(1.81)$ & & $365(1.45)$ & $89(0.37)$ \\
\hline Middle executive professionals & $434(1.89)$ & & $313(1.35)$ & $121(0.54)$ \\
\hline Skilled employees & $203(1.83)$ & & $160(1.44)$ & $43(0.39)$ \\
\hline Low-skilled employees & $356(1.56)$ & & $254(1.10)$ & $102(0.45)$ \\
\hline Skilled manual workers & $125(0.99)$ & & $87(0.68)$ & $38(0.31)$ \\
\hline Low-skilled manual workers & $62(1.11)$ & & $38(0.76)$ & $24(0.34)$ \\
\hline Never worked and others & $326(1.28)$ & & $241(0.93)$ & $85(0.35)$ \\
\hline Standard of living (in deciles) & & 0.003 & & \\
\hline D1 & $209(1.41)$ & & $140(0.92)$ & $69(0.49)$ \\
\hline D2-D3 & $316(1.33)$ & & $221(0.94)$ & $95(0.39)$ \\
\hline D4-D5 & $349(1.49)$ & & $255(1.10)$ & $94(0.39)$ \\
\hline D6-D7 & $389(1.47)$ & & $295(1.10)$ & $94(0.37)$ \\
\hline D8-D9 & $519(1.77)$ & & $388(1.32)$ & $131(0.45)$ \\
\hline D10 & $247(1.74)$ & & $209(1.46)$ & $38(0.28)$ \\
\hline Formal education & & $<0.001$ & & \\
\hline No diploma & $123(1.43)$ & & $82(0.89)$ & $41(0.54)$ \\
\hline Primary education & $74(1.03)$ & & $53(0.77)$ & $21(0.25)$ \\
\hline Vocational secondary & $335(1.17)$ & & $229(0.80)$ & $106(0.36)$ \\
\hline High school & $467(1.48)$ & & $330(1.03)$ & $137(0.44)$ \\
\hline High school+2-4 years & $663(1.82)$ & & $502(1.38)$ & $161(0.44)$ \\
\hline High school +5 or more years & $390(1.95)$ & & $325(1.62)$ & $65(0.33)$ \\
\hline Working arrangement during lockdown & & $<0.001$ & & \\
\hline Not working and others & $669(1.33)$ & & $484(0.96)$ & $185(0.38)$ \\
\hline Remote working only & $376(1.79)$ & & $308(1.46)$ & $68(0.33)$ \\
\hline Working outside the home partly or only & 1007 (1.62) & & $729(1.16)$ & $278(0.45)$ \\
\hline
\end{tabular}




\begin{tabular}{|c|c|c|c|c|}
\hline & $\begin{array}{l}\text { Anosmia/ } \\
\text { ageusia, }{ }^{*} \\
\mathrm{n}=2052(1.53 \%)\end{array}$ & $\mathrm{P}$ valuet & $\begin{array}{l}\text { Anosmia/ageusia } \\
\text { during peak, } n=1521 \\
(1.12 \%)\end{array}$ & $\begin{array}{l}\text { Anosmia/ } \\
\text { ageusia after } \\
\text { peak, } n=531 \\
(0.41 \%)\end{array}$ \\
\hline High density of the place of residence & & $<0.001$ & & \\
\hline No & $1078(1.21)$ & & $778(0.85)$ & $300(0.36)$ \\
\hline Yes & $974(2.04)$ & & $743(1.56)$ & $231(0.49)$ \\
\hline Overcrowded housing & & $<0.001$ & & \\
\hline No & $1719(1.44)$ & & $1280(1.07)$ & $439(0.37)$ \\
\hline Yes & $333(2.12)$ & & $241(1.47)$ & $92(0.64)$ \\
\hline Number of persons living in the house & & $<0.001$ & & \\
\hline 1 & $232(1.34)$ & & $175(1.01)$ & $57(0.33)$ \\
\hline 2 & $472(1.28)$ & & $348(0.94)$ & $124(0.35)$ \\
\hline $3-4$ & $979(1.61)$ & & $720(1.17)$ & $259(0.44)$ \\
\hline 5 or more & $369(1.95)$ & & $278(1.46)$ & $91(0.49)$ \\
\hline Essential occupation & & $<0.001$ & & \\
\hline No & $1193(1.39)$ & & $908(1.05)$ & $285(0.34)$ \\
\hline Healthcare workers & $205(2.94)$ & & $131(1.78)$ & $74(1.16)$ \\
\hline Others & $654(1.61)$ & & $482(1.18)$ & $172(0.43)$ \\
\hline Region & & $<0.001$ & & \\
\hline Least affected regions & $866(1.04)$ & & $622(0.73)$ & $244(0.31)$ \\
\hline Grand Est & $305(2.15)$ & & $242(1.72)$ & $63(0.43)$ \\
\hline Hauts-de-France & $215(1.50)$ & & $147(1.03)$ & $68(0.47)$ \\
\hline Ile-de-France & $666(2.85)$ & & $510(2.16)$ & $156(0.68)$ \\
\hline
\end{tabular}

Data are presented as $\mathrm{n}(\%)$.

Significant $\chi^{2}$ tests are indicated in bold.

*Symptoms were recorded if they occured between the 17 March 2020 and the date of survey (from 2 May to 2 June 2020).

$+\chi^{2}$ test for anosmia/ageusia during the whole period (yes or no).

DOM, French Overseas Departments.

first epidemic peak, which would have been masked by an analysis over the whole period.

Our results point that women and ethnoracial minorities were at higher risk of anosmia/ageusia during the peak and after. While senior executive professionals were more affected than lower social classes at the peak of the epidemic, this effect disappeared after.

We show that important exposure factors likely to increase contact with the virus, that is, the density of the place of residence, living in overcrowded housing and having worked outside the home during lockdown ${ }^{4} 17$ have not been evenly distributed across social groups and also that some social groups do cumulate these risk factors. Hence, racialised minorities, the least educated, and those with the lowest financial resources are particularly affected by living in densely populated communities and overcrowded housing. These data reflect the well-documented effects of sociospatial segregation policies. ${ }^{20}$ Furthermore, among those who continued to work during lockdown, working class groups have been more likely to work outside the home than senior managers who were able to work remotely to a large extent.

\section{Interpretation of findings}

The persistent increased risk of anosmia/ageusia among women compared with men are likely to reflect occupational specificities, beyond the categories used here. Indeed, women are over-represented in the nursing and care assistant occupations as well as in cleaning activities. ${ }^{22}$ In addition, they take care of children and the elderly, ${ }^{23}{ }^{24}$ which may increase their social contacts. This greater exposure of women raises questions as they are shown to be less likely to die from COVID-19 than men, which may partly reflect their lower rates of comorbidities. ${ }^{5}$

With regard to ethnoracial status, the persistent higher risk of reporting anosmia/ageusia among racialised people was not linked to a lower propensity to wear a mask. ${ }^{11}$ It may instead be indicative of social contacts in neighbourhoods where the circulation of the virus was and remained higher over time, as suggested by our results, since their increased risk was substantially attenuated after adjusting for density of place of residence and overcrowded housing. Understanding determinants of infection among those minorities throughout the 
Table 2 Sociodemographic characteristics associated with COVID-19 risk factors

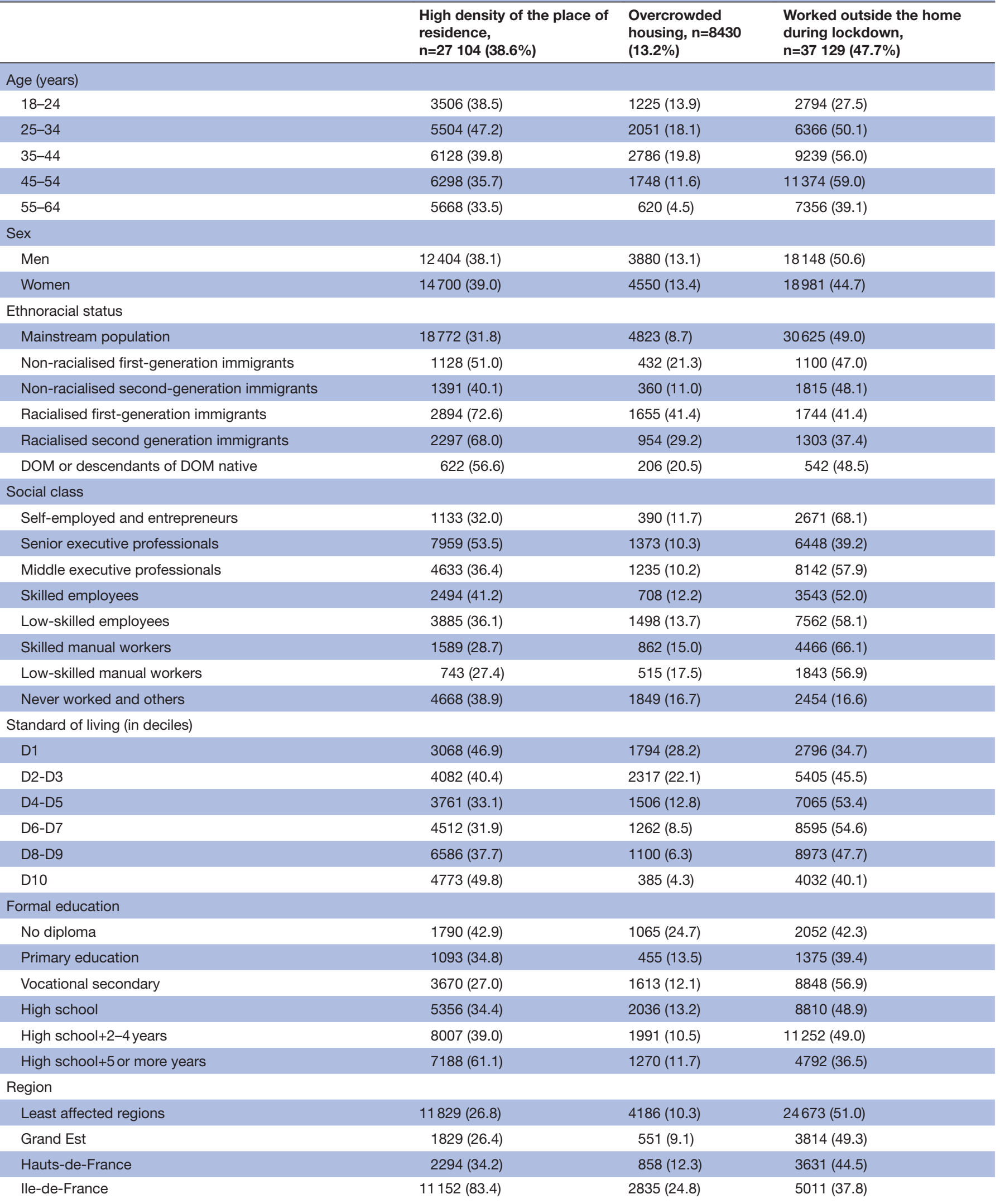

Data are presented as $\mathrm{n}(\%)$.

All sociodemographic variables were significantly associated with each three COVID-19 exposure risk factors ( $p$ value $<0.001, \chi^{2}$ tests), except sex with high density ( $p$ value $=0.051$ ) and overcrowded housing ( $p$ value $=0.30$ )

DOM, French Overseas Departments. 


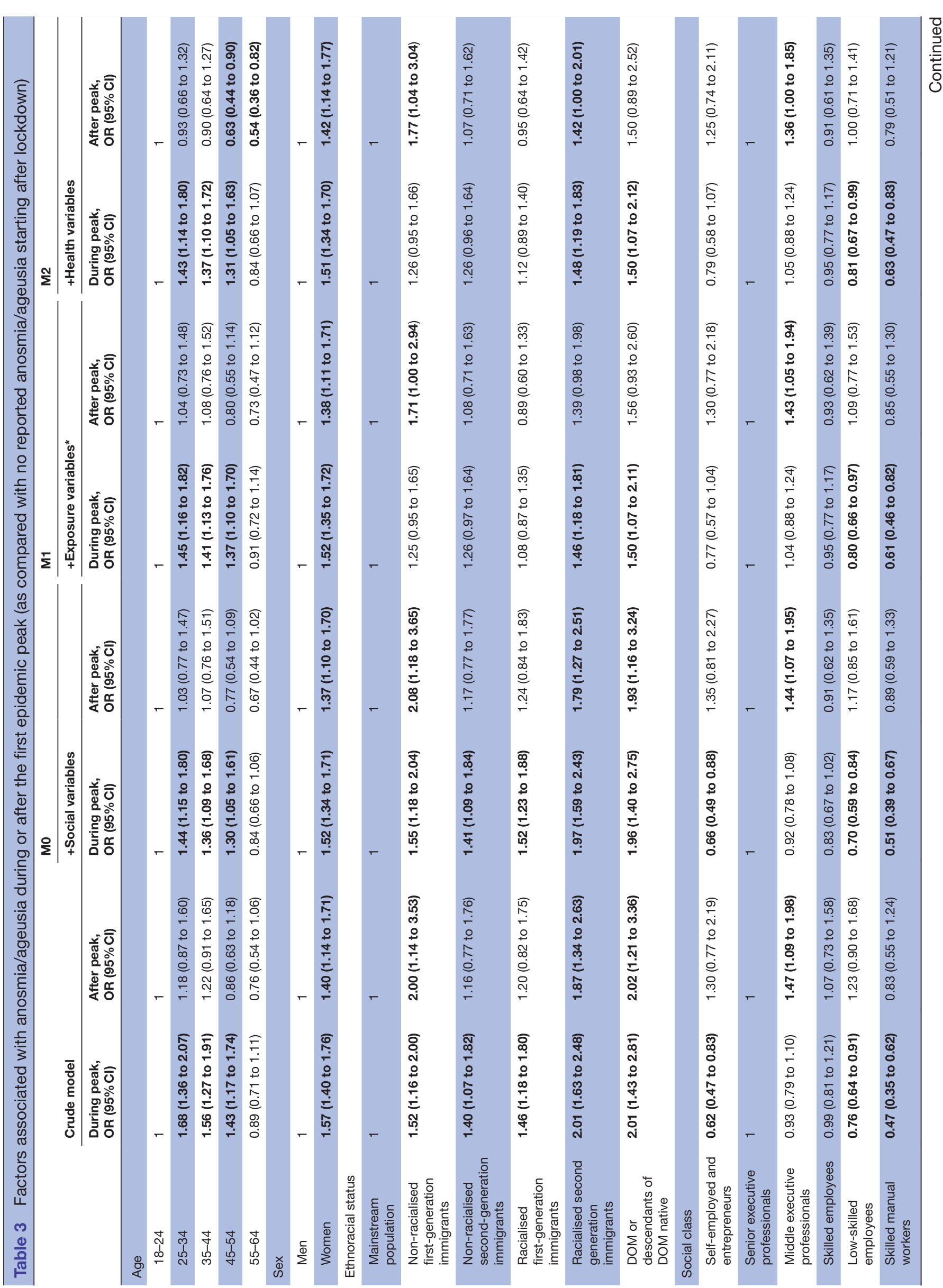




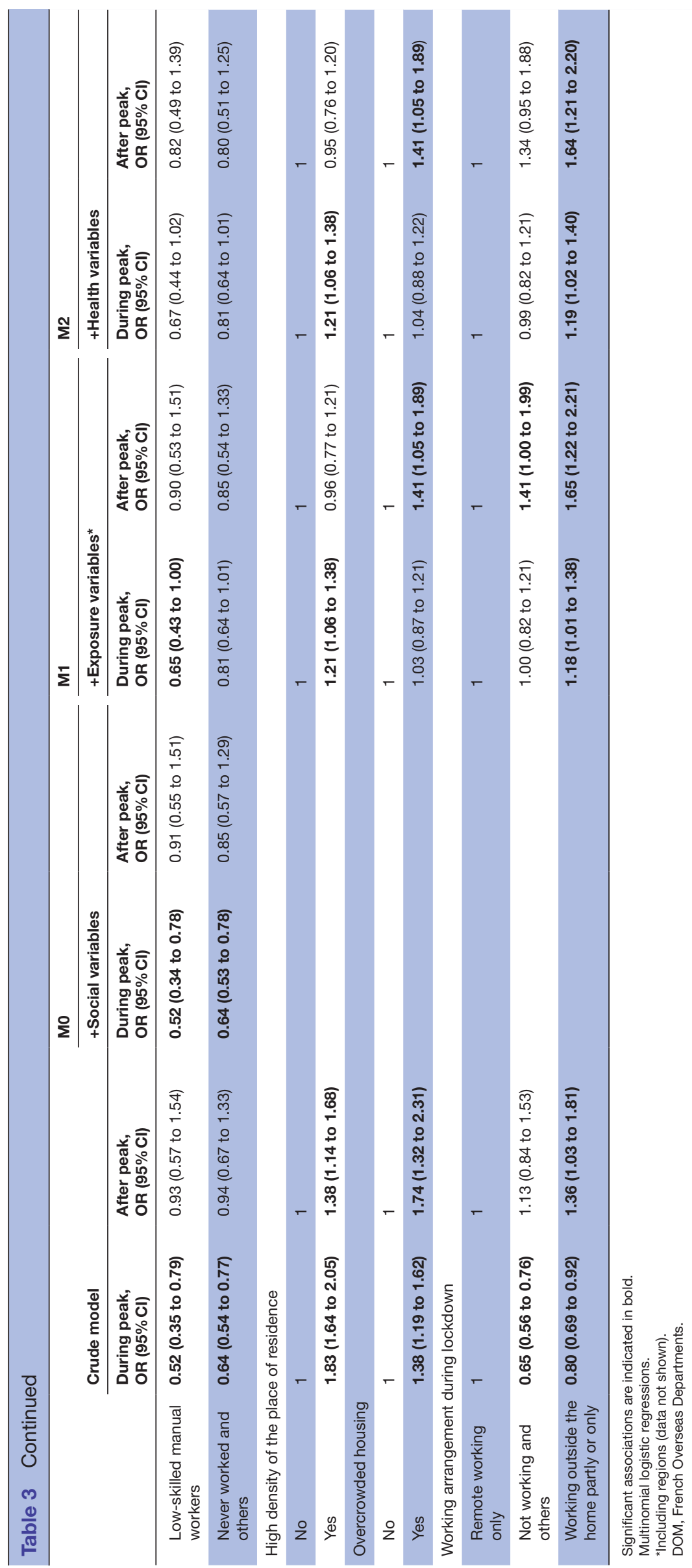

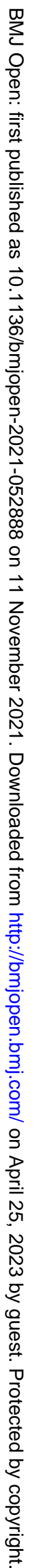


epidemic is all the more so important as a higher likelihood of dying from COVID-19 was reported in many countries, including France. ${ }^{5925}$

Whereas senior executive professionals were more affected than lower social classes at the peak of the epidemic, this effect disappeared afterwards. Only middle executive professionals were at higher risk during the epidemic decline, which was likely due to the presence of health professionals, particularly nurses, in this group, as this association totally disappeared when further adjusted for essential occupations. The increased risk among essential occupations was particularly sharp for health professionals, due to the continuous care provided to patients with a high viral load. ${ }^{16}$ It is important to note that the other so-called essential occupations were overexposed after the peak of the epidemic; this group includes those in regular contact with the public such as cashiers, bus drivers, etc. Such results call for an in-depth and longitudinal analysis of occupational disparities in COVID-19 exposure based on the combination of type of job (eg, healthcare, high-contact jobs, etc), working arrangement (remote, on-site, layoff), as well as implementation of preventive measures at the worksite. Indeed, the higher risk of infection of people who worked outside the home during lockdown was particularly marked after the peak of the epidemic, that is, during a period of epidemic decline when contact with the virus was proportionally more marked among on-site workers as compared with people who stayed at home.

It should also be noted that the density of the place of residence was no longer related to the reporting of anosmia/ageusia occurring after the peak of the epidemic probably because the virus circulates less in the neighbourhood, thanks to the lockdown. On the contrary, overcrowding was significantly associated after the peak only, probably due to the higher risk of COVID-19 transmission linked to unavoidable close proximity and/or large number of people in the household. Background rates and circulation patterns of SARS-CoV-2 should be considered while looking at the social and spatial dynamics of the epidemic, ${ }^{26}$ as they influence the relative importance of community and workplace transmission. ${ }^{27}$

\section{Study limitations}

Our analysis has nevertheless some limitations. First, as any national population-based survey, the study fails to capture highly vulnerable groups such as undocumented migrants and homeless people, who are particularly affected by the pandemic. ${ }^{28}$

Additionally, due to a shortage of tests at the national level in the early stage of the epidemic, our analyses are based on reported symptoms of anosmia/ageusia rather than on biologically confirmed cases. This excludes infected people reporting other symptoms, and of course asymptomatic individuals who represent one out of six of the infected population according to a recent meta-analysis. ${ }^{29}$
Although anosmia/ageusia reporting may be socially differentiated, especially due to differences in recognition of symptoms, it is reasonable to assume that such a bias did not vary during the month of the survey. One might also think that women are more likely to report anosmia/ageusia since they have a heightened sense of smell compared with men, as shown by sociological studies. ${ }^{30}$ Nevertheless, the ratio of women to men reporting such symptoms is only slightly larger than that recorded for seroprevalence in a subsample of the same cohort $^{31}$ as found in other European countries. ${ }^{32}$

We chose to focus on anosmia/ageusia only, which are the most specific symptoms of COVID-19, ${ }^{18}$ so that our analyses would be more robust. ${ }^{33}$ Indicative of internal validity, our results are consistent with epidemiological surveillance data by region ${ }^{34}$ as well as with data on increased risk of infection in people with chronic conditions ${ }^{1635}$ and instead a protective effect of smoking. ${ }^{36}$

Finally, while it was not possible to build clear-cut periods of 'likely infection' based on the timing of symptoms reported by the participants, the broad distinction made between people for whom symptoms started during the epidemic peak versus after it allowed us to compare an early stage of the epidemic with the phase of decline in the incidence corresponding to the first lockdown in France.

\section{CONCLUSION}

To our knowledge, EpiCoV is one of the first socioepidemiological surveys conducted among a very large random sample of a national population that simultaneously considers living conditions and health data and allows for an intersectional analysis of social inequalities by gender, ethnoracial status and social class. Our results show the importance of closely monitoring social changes over time to implement prevention policies that do not contribute to increasing the already significant social inequalities in health. In all, the associations reported during the epidemic peak-lower exposures among low-skilled jobs than senior executives, overexposure among all ethnoracial minorities compared with the majority population, with a strong influence of overcrowding and population density - are likely to reflect the social profile and associated risk factors that prevailed just before the implementation of stay-at-home measures and national lockdown. By contrast, those observed after the peak point to a shift in the social profile of the epidemic related to a shift in exposure factors under the implementation of stringent collective prevention measures. They notably stress the importance of working outside the home, all the more so in essential occupations, particularly, though not exclusively, for healthcare workers. ${ }^{37}$ The persistent excess risk among women and some ethnoracial minorities call for further research. 
Author affiliations

${ }^{1}$ Institut de Recherche Interdisciplinaire sur les enjeux Sociaux - Sciences sociales, politique, santé, IRIS (UMR 8156 CNRS - EHESS - U997 INSERM), Aubervilliers,

France

${ }^{2}$ INED, Paris, France

${ }^{3}$ Université Paris Dauphine, Paris, France

${ }^{4}$ ARENES UMR 6051, CNRS, EHESP, Rennes, France

${ }^{5}$ Santé publique France, Saint-Maurice, France

${ }^{6}$ University Grenoble Alpes, INSERM, CNRS, Institute for Advanced Biosciences,

Grenoble, France

${ }^{7}$ INSERM, Université Paris-Saclay, AP-HP, Paris, France

Acknowledgements The authors warmly thank all the volunteers of the Epidémiologie et Conditions de Vie (EpiCoV) cohort. We would like to thank the DREES and INSEE teams for the creation of the sample, the calculation of the survey weights and the logistics of the survey. We would like to thank the staff of the IPSOS team that have worked with dedication and engagement to collect and manage the data used for this study. We would also like to thank the INSERM Sante Publique team, especially Sylvain Durrleman, and Frédéric Robergeau, responsible for the management of the database.

Collaborators EpiCoV study group: Nathalie Bajos (co-principal investigator), Josiane Warszawski (co-principal investigator), Guillaume Bagein, Muriel Barlet, François Beck, Emilie Counil, Florence Jusot, Aude Leduc, Nathalie Lydie, Claude Martin, Laurence Meyer, Ariane Pailhé, Nicolas Paliod, Delphine Rahib, Philippe Raynaud, Alexandra Rouquette, Patrick Sicard, Rémy Slama, Alexis Spire.

Contributors NB, as guarantor, had full access to all the data in the study and takes responsibility for the integrity of the data and the accuracy of the data analysis. IPSOS collected data. NB, EC and J-eF provided the study concept and design. J-eF made the statistical analysis and NB, EC, J-eF, LM and JW interpreted the results. RS obtained funding. NL contributed as administrative support. NB and JW supervised the study. NB, EC and J-eF drafted the first manuscript, and all authors contributed to the final manuscript.

Funding This research was funded by INSERM (Institut National de la Santé et de la Recherche Médicale), French Ministry for Research, Drees (Direction de la Recherche, des Études, de l'Évaluation et des Statistiques) and the European Research Council under the European Union's Horizon 2020 research and innovation program (856478).

Competing interests None declared.

Patient consent for publication Not applicable.

Ethics approval The survey was approved by the CNIL (French independent administrative authority responsible for data protection) on 25 April 2020 (ref: MLD/MFI/AR205138) and by the 'Comité de protection des personnes' (French equivalent of the Research Ethics Committee) on 24 April. The survey also obtained an agreement from the 'Comité du Label de la statistique publique', proving its adequacy to statistical quality standards.

Provenance and peer review Not commissioned; externally peer reviewed.

Data availability statement Data are available on reasonable request. Data are available from the corresponding author on reasonable request.

Supplemental material This content has been supplied by the author(s). It has not been vetted by BMJ Publishing Group Limited (BMJ) and may not have been peer-reviewed. Any opinions or recommendations discussed are solely those of the author(s) and are not endorsed by BMJ. BMJ disclaims all liability and responsibility arising from any reliance placed on the content. Where the content includes any translated material, BMJ does not warrant the accuracy and reliability of the translations (including but not limited to local regulations, clinical guidelines, terminology, drug names and drug dosages), and is not responsible for any error and/or omissions arising from translation and adaptation or otherwise.

Open access This is an open access article distributed in accordance with the Creative Commons Attribution Non Commercial (CC BY-NC 4.0) license, which permits others to distribute, remix, adapt, build upon this work non-commercially, and license their derivative works on different terms, provided the original work is properly cited, appropriate credit is given, any changes made indicated, and the use is non-commercial. See: http://creativecommons.org/licenses/by-nc/4.0/.

ORCID iDs

Nathalie Bajos http://orcid.org/0000-0001-8073-9056

Emilie Counil http://orcid.org/0000-0002-8527-4662
Jeanna-eve Franck http://orcid.org/0000-0002-3585-8643

\section{REFERENCES}

1 Bambra C, Riordan R, Ford J, et al. The COVID-19 pandemic and health inequalities. J Epidemiol Community Health 2020;74:964-8.

2 Shadmi E, Chen Y, Dourado I, et al. Health equity and COVID-19: global perspectives. Int J Equity Health 2020;19:104.

3 Wang Z, Tang K. Combating COVID-19: health equity matters. Nat Med 2020;26:458.

4 Wachtler B, Hoebel J. [Social Inequalities and COVID-19: SocialEpidemiological Perspectives on the Pandemic]. Gesundheitswesen 2020;82:670-5

5 Williamson EJ, Walker AJ, Bhaskaran K, et al. Factors associated with COVID-19-related death using OpenSAFELY. Nature 2020;584:430-6.

6 Sze S, Pan D, Nevill CR, et al. Ethnicity and clinical outcomes in COVID-19: a systematic review and meta-analysis. EClinicalMedicine 2020;29:100630.

7 Meyerowitz-Katz G, Merone L. A systematic review and metaanalysis of published research data on COVID-19 infection fatality rates. Int J Infect Dis 2020;101:138-48.

8 Wright L, Steptoe A, Fancourt D. Are we all in this together? Longitudinal assessment of cumulative adversities by socioeconomic position in the first 3 weeks of lockdown in the UK. J Epidemiol Community Health 2020;74:683-8.

9 Jefferies S, French N, Gilkison C, et al. COVID-19 in New Zealand and the impact of the National response: a descriptive epidemiological study. Lancet Public Health 2020;5:e612-23.

10 Yang B, Wu P, Lau EHY. Changing disparities in COVID-19 burden in the ethnically homogeneous population of Hong Kong through pandemic waves: an observational study. Clin Infect Dis 2021. doi:10.1093/cid/ciab002

11 Bajos NW, Pailhé J.;, Counil A.; et al. Les inégalités sociales au temps du COVID-19. Questions de Santé Publique2020; N40.

12 Rutter PD, Mytton OT, Mak M, et al. Socio-Economic disparities in mortality due to pandemic influenza in England. Int J Public Health 2012;57:745-50.

13 Lowcock EC, Rosella LC, Foisy J, et al. The social determinants of health and pandemic H1N1 2009 influenza severity. Am J Public Health 2012;102:e51-8.

14 Bauer GR. Incorporating intersectionality theory into population health research methodology: challenges and the potential to advance health equity. Soc Sci Med 2014;110:10-17.

15 Milner A, Jumbe S. Using the right words to address racial disparities in COVID-19. Lancet Public Health 2020;5:e419-20.

16 Carrat F, Touvier M, Severi G, et al. Incidence and risk factors of COVID-19-like symptoms in the French general population during the lockdown period: a multi-cohort study. BMC Infect Dis 2021;21:169.

17 Ward H, Atchison C, Whitaker M, et al. SARS-CoV-2 antibody prevalence in England following the first peak of the pandemic. Nat Commun 2021;12:905.

18 Vos ERA, den Hartog G, Schepp RM, et al. Nationwide seroprevalence of SARS-CoV-2 and identification of risk factors in the general population of the Netherlands during the first epidemic wave. J Epidemiol Community Health 2020. doi:10.1136/jech-2020215678. [Epub ahead of print: 28 Nov 2020].

19 Agyeman AA, Chin KL, Landersdorfer CB, et al. Smell and taste dysfunction in patients with COVID-19: a systematic review and meta-analysis. Mayo Clin Proc 2020;95:1621-31.

20 Beauchemin CH C, Simon P. Trajectories and origins: survey on the diversity of the French population. Springer, 2018.

21 Warszawski J, Bajos N, Barlet M. A national mixed-mode seroprevalence random population-based cohort on SARS-CoV-2 epidemic in France: the socio-epidemiological EpiCov study. medRxiv2021.

22 Argouarc'h J, Calavrezo O. La répartition des hommes et des femmes par métiers : une baisse de la ségrégation depuis 30 ans. Dares analyses2013;79.

23 Besnard XB, Couvert M.; N.; Roy D. Les proches aidants des seniors et leur ressenti sur l'aide apportée - Résultats des enquêtes « CARE " auprès des aidants (2015-2016). Les dossiers de la DREES2019;45.

24 Pailhé A, Solaz A, Stanfors M. The great convergence: gender and unpaid work in Europe and the United States. Popul Dev Rev 2021;47:181-217.

25 SR-BI P. Une hausse des décès deux fois plus forte pour les personnes nées l'étranger que pour celles nées en France en marsavril 2020. Insee Focus2020;198.

26 Jay J, Bor J, Nsoesie EO, et al. Neighbourhood income and physical distancing during the COVID-19 pandemic in the United States. Nat Hum Behav 2020;4:1294-302. 
27 Ossimetha A, Ossimetha A, Kosar CM, et al. Socioeconomic disparities in community mobility reduction and COVID-19 growth. Mayo Clin Proc 2021;96:78-85

28 Tsai J, Wilson M. COVID-19: a potential public health problem for homeless populations. Lancet Public Health 2020;5:e186-7.

29 Byambasuren OC, Bell M.;, Clark K.; , et al. Estimating the extent of asymptomatic COVID-19 and its potential for community transmission: systematic review and meta-analysis. Off J Assoc Med Microbiol Infect Dis Can 2020;5:223-34.

30 Sorokowski P, Karwowski M, Misiak M, et al. Sex differences in human olfaction: a meta-analysis. Front Psychol 2019;10:242.

31 Jea W, May I. 4.5\% of the population of metropolitan France had developed antibodies against SARS-CoV-2. The first results of the EpiCov national survey. Etudes et Résultats 2020;N²020;1167.

32 Lechien JR, Chiesa-Estomba CM, De Siati DR, et al. Olfactory and gustatory dysfunctions as a clinical presentation of mildto-moderate forms of the coronavirus disease (COVID-19): a multicenter European study. Eur Arch Otorhinolaryngol 2020;277:2251-61.

33 Rothman KG S. Modern epidemiology. 2nd Edition. Lippincott Williams \& Wilkins, 1998.

34 Indicateurs de suivi de l'épidémie de COVID-19T. Available: https:// www.data.gouv.fr/fr/datasets/indicateurs-de-suivi-de-lepidemie-decovid-19/ [Accessed Apr 2021]

35 Halpin DMG, Faner R, Sibila O, et al. Do chronic respiratory diseases or their treatment affect the risk of SARS-CoV-2 infection? Lancet Respir Med 2020;8:436-8.

36 Zhao Q, Meng M, Kumar R, et al. The impact of COPD and smoking history on the severity of COVID-19: a systemic review and metaanalysis. J Med Virol 2020;92:1915-21.

37 Fisher KA, Olson SM, Tenforde MW, et al. Telework Before Illness Onset Among Symptomatic Adults Aged $\geq 18$ Years With and Without COVID-19 in 11 Outpatient Health Care Facilities - United States, July 2020. MMWR Morb Mortal Wkly Rep 2020;69:1648-53. 